\title{
"Entrepreneurial resilience: the case of Somali grocery shop owners in a South African township"
}

AUTHORS

ARTICLE INFO

DOI

RELEASED ON

JOURNAL

FOUNDER
Robertson K. Tengeh

Robertson K. Tengeh (2016). Entrepreneurial resilience: the case of Somali grocery shop owners in a South African township. Problems and Perspectives in Management, 14(4-1), 203-211. doi:10.21511/ppm.14(4-1).2016.09

http://dx.doi.org/10.21511/ppm.14(4-1).2016.09

Friday, 23 December 2016

"Problems and Perspectives in Management"

LLC "Consulting Publishing Company "Business Perspectives"

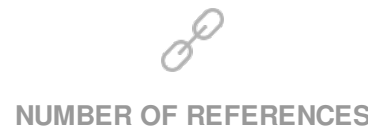

0
NUMBER OF FIGURES

0

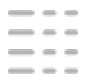

NUMBER OF TABLES

0

(C) The author(s) 2022. This publication is an open access article. 
Robertson K. Tengeh (South Africa)

\title{
Entrepreneurial resilience: the case of Somali grocery shop owners in a South African Township
}

\begin{abstract}
Most studies on entrepreneurship have highlighted the relative importance of a conducive environment for the development of entrepreneurship. This notwithstanding, entrepreneurship has been noted to thrive even under the most adverse conditions, such as during economic, social and political instabilities. Using resilience as the propensity to bounce back after adversity and xenophobia, crime, unhealthy competition, etc. as correlates of adversity or an unconducive business environment, this paper investigated the preponderance of Somali grocery shops in South African township despite the perceived hostility of the business environment. Anchored on the qualitative research approach, a purposive sample of 13 participants provided the required data for analysis. Specifically, the data collection took the form of focus group interviews in which two groups of 6 and 7 informants were purposively selected to be part of the interviews. Prominent in the results was the fact that almost all the current Somali grocery shops in the study area have been victims of crime and theft. Furthermore, virtually all the Somali grocery shops that were victimized during the xenophobic outburst have since re-opened. The foregoing themes of resilience and adversity unmistakably indicate the propensity of Somali grocery shop owners' ability to bounce back. As to what township entrepreneurs worry or fear most, clearly the fear of the re-occurrence of the xenophobic attacks surpassed that of burglary, theft and death. As to what fuels Somali's persistence and preponderance in townships, both push and pulled factors were reported. Reporting on risk aversion, it was noted that most of the founders (here referred to as an entrepreneur) are not actively involved in running the shops. They simply recruit others to do the job on their behalf. Under this circumstance, the risk is limited to financial risk. This approach is quite different for other African immigrants in the same township.
\end{abstract}

Keywords: entrepreneurship, turbulent business environment, xenophobia, entrepreneurial resilience, South Africa townships.

JEL Classification: M00.

\section{Introduction}

It is widely believed that a conducive environment is necessary for the successful startup and growth of a business (Fairlie, 2009; Sadeghi, Mohammadi, Nosrati \& Malekian, 2013). However, the extent to which this environment can be conducive for business startup and growth remains questionable and contestable. Drawing on the foregoing would mean that certain environments are more favorable for business startup and operation than others. One must admit that the mere conduciveness of an environment does not instantly translate into flourishing businesses. This is particularly so because the ability to start-up or grow a business inherently depends on the individual (internal factors) besides external factors (Tengeh, 2013). Without a strong entrepreneurial drive and resilience, one would expect limited or no entrepreneurial activities in volatile or precarious business environments.

\section{Background to the research problem}

Proponents of the relevancy of a conducive environment for the developmemnet of entrepreneurship, emphasizes a stability of a number of variables including political, economic, and social. In view of the antecedent, it seems stability cannot be compromised if entrepreneurship is to triumph. Howev-

(C) Robertson K. Tengeh, 2016.

Robertson K. Tengeh, Faculty of Business \& Management Sciences, Cape Peninsula University of Technology, South Africa. er, conflicting views have been noted in a number of studies (Naudé, 2009; Bruck, Naudé, \& Verwimp, 2013). These authors clearly document entrepreneurship survival despite devastating political, economic and social conditions. For instance during and after serious conflicts, devastation and so forth. Besides the desire to take advantage of the opportunities presented during challenging times, it is not yet clear why some entrepreneurs will put their lives on the line in the process.

The instability takes a variety of forms not limited to wars, violence, unhealthy competition, gang wars, xenophobia and so forth. The literature presupposes that entrepreneurial activities decline in the face of such challenges. This notwithstanding, it has also been noted that some entrepreneurs or areas affected tend to bounce back sooner than others. Understanding why certain groups of entrepreneurs or societies are more resilient to these hostile conditions than others may provide valuable lessons. This is especially true in the context of township businesses in South Africa where xenophobia and other adverse conditions have tested the resilience of African immigrant entrepreneurs.

A number of xenophobic insurgencies against African immigrants ensued in South Africa in the past couple of years. Of particular relevance were the 2008, 2010 and 2015 attacks. In 2008, the attack displaced close to 20000 immigrants in the Western Cape Province alone (Vromans, Schweitzer, Knoetze, \& Kagee, 2011). 
Although many African businesses were affected, those owned by Somali were in the majority. Among other reasons, one may suggest that their sheer numbers in these townships made them "statistics." Many Somalis-owned businesses were ravaged and ransacked (Duncan, 2010). Coincidentally, Somali merchants and businesses have been increasingly targeted for violence and robbery (Grastow \& Amit, 2012) and this is perhaps due to the propensity of Somali traders to work anywhere, including townships. In spite of these setbacks, Somali grocery shops seem to dominate and flourish in South African townships today. All things being the same, this paints a picture of entrepreneurial resilience.

\section{The problem and research questions}

Inquiry in a number of settings suggests that actions of entrepreneurs result in more resilient organizations and economic systems that better withstand disruptions and recover quicker. Nevertheless, not much is known about the factors that contribute to an entrepreneur's potential to rebound and thrive in a tempestuous business environment. Using immigrant businesses in South African townships as the focal point, with particular reference to Somalis' grocery businesses, this study sought to understand how Somalis' grocery businesses thrived in a turbulent business environment in the township. The lessons drawn from this study may assist similar communities, organizations and regions to foster entrepreneurial activities that are better prepared to deal with a variety of possible challenges.

Highlighted by few authors (see Naudé, 2009; Bruck, Naudé, \& Verwimp, 2013) the current entrepreneurship literature seems to be passive on the discussion and understanding of resilience, even though resilience and entrepreneurship have many attributes in common, including; pro-activity, flexibility, adaptiveness, and innovativeness.

Though entrepreneurial activity is often steadfast during turbulent times, Naudé (2009) contends that it has to adapt to modes that are sometimes not the best for economic development. In many ways, this assertion points toward the need for intervention.

South African townships have been a host to many immigrant entrepreneurs, and their numbers have risen over the past years. Interestingly, while the number of immigrants from different nations temporarily reduced after the xenophobic attacks, the number of Somali-owned shops have persistently been on the rise. Almost all that flee have returned. Given the persistent negative sentiments held towards immigrants and their businesses, understanding why these immigrants return to these townships and how they thrive under such volatile conditions may provide meaningful pointers for intervention. In the context of Somali traders who still make up the majority of African immigrant entrepreneurs in these townships, one would like to understand:

- How risky is township entrepreneurship?

- Why do Somali-owned businesses thrive in South African townships, despite the volatile business environment?

- What survival strategies do Somali entrepreneurs utilised by to mitigate the precarious business environment in South African Township?

\section{Literature review}

3.1. Entrepreneurship and entrepreneurial resilience. In the last 66 years, entrepreneurship has gained traction as a major topic in the theory and practice of economic growth and development. The metamorphosis undergone during this developmental process has led a plethora of definitions. Hence, there is no "one size that fits all" definition of entrepreneurship (Anderson \& Starnawska, 2008). Stemming from this, most definitions of entrepreneurship tend to incorporate some elements of the following: the environment in which entrepreneurial activity occurs; the individuals involved in entrepreneurship; entrepreneurial behaviors demonstrated by entrepreneurs; innovation; assuming risk; and adding value for the entrepreneur and society. Interestingly, most progressive definitions of entrepreneurship tend to enforce the need for a conducive business environment (Barringer \& Ireland, 2010; Nieman \& Nieuenhuizen, 2009). This notwithstanding, a number of authors (see Bruck et al., 2013) have highlighted entrepreneurial success in deplorable business settings. Thus, Hedner, Abouzeedan and Kloften (2005) call for a definition of entrepreneurship that fully incorporates resilience as a trait.

3.1.1. The concept of resilience, risk and entrepreneurship. As a concept that owes its origin to the field of psychology, resilience describes a person who adapts positively in a stressful or volatile environment. This assertion presupposes two critical conditions: (a) an imminent threat or severe adversity (Cramer, Hartog, Jonker, \& van Praag, 2002; Luthar et al., 2003); and (b) an extraordinary adaptation in the face of a major assault on the developmental progression (Luthar, Cicchettit, \& Becker, 2000; Wermer \& Smith, 1992; De Vries \& Shields, 2005).

Resilience as a concept fosters our comprehension of how organizations and local communities work and respond to exogenous shocks (De Vries \& Shields, 2005). This is particularly true in the case of organizations that demonstrate reliable and extraordinary performance in stressful situations. Resilience has attracted much attention where organi- 
zations exhibit high reliability and superior performance under stress or the lack of it. Inquiry in a number of settings suggests that actions of entrepreneurs result in more resilient organizations and economic systems that better withstand disruptions and recover quicker. The concept of resilience presupposes the exposure to significant risks (Cramer et al., 2002; Luthar et al. 2003). In fact, it is believed that risk is a critical component of the entrepreneurial function, and the entrepreneur's ability to manage risk is crucial to the creation of new start-ups. Given that risk is embedded in entrepreneurial activities, every organization seeks to minimise its impact by preparing.

Although many may disagree as to whether the nature and degree of threats have changed over the years, The Economist (2007) notes that there is little doubt about the imminent increase in the attention given to preparing for them. Hence, one may draw that while business-related risks have widened over the years, the focus on operational risk has remained the same, with even a lesser concern for the safety of the entrepreneurs and employees.

3.2. Personal characteristics of entrepreneurs in volatile environments. An entrepreneur is a person who conceptualizes an idea, assumes the risk of mobilizing the resources to realize and manage the startup (Nieman \& Pretorius, 2004; Fuchs, Werner $\&$ Wallau, 2008). This basic definition presupposes that risk is inherent in entrepreneurship that may be triggered or compounded by a number of factors not limited to violence, xenophobic attacks, armed robbery, many creditors, lack of access to finance as is the case in the South Africa townships.

Given that every business opportunity tend to be unique, there is no single set of attributes that every entrepreneur must have to explore them. Perhaps a combination of attributes would be required, taking into consideration, the uniqueness of the opportunity, and the founder's strengths and weaknesses (Rwigema \& Venter, 2004).

In spite of the perceived variances in the requisite characteristics there is an accord that prosperous entrepreneurs are shaped by a set of character traits. In support, Barringer and Ireland (2008) distinguished a passion for business, execution, intelligence and perseverance in spite of failure as the four major characteristics of successful entrepreneurs. Concurring, that a good entrepreneur has indubitable characteristics concerning volatile environments, Rwigema and Venter (2004) add commitment, self-reliance and tenacity to the list.

One may argue that an entrepreneur in a volatile environment must have a high degree of risk-taking attributes as well as be very patient and prudent in his business dealings in order to survive in such an environment. Furthermore, as De Vries (1977) advances, both external and internal attitudes towards entrepreneurial failure become the factors that contribute to the willingness of entrepreneurs to start or pursue their entrepreneurial ambitions in the face of challenges and adversity.

3.3. Conditions favorable and unfavorable to entrepreneurship. Favorable conditions are those that support the start-up and growth of entrepreneurial ventures.Unlike a favorable environment, an erratic or unfavorable business environment discourages the startup and growth of businesses. Thus, an unstable business environment may be the result of different causes, including insecurity; political; and economic instability. In general, the number of factors not limited to: political, social, geographical and economical factors could be the trigger to a favorable or unfavorable business environment.

Overall, it is expected that a stable and secure business environment is essential for a business owner, employee, customers and hence the survival of the business. For instance, favorable economic conditions would ensure that entrepreneurs have access to; financial, human, and physical and information resources and so forth (Nieman \& Nieunhuizen, 2009).

Although these forces do not occur in isolation, the impact of a political factor is far reaching and, can support or suppress entrepreneurship. For instance, political environment influences entrepreneurship in a number of ways including:

- Frequent changes in government policies, which makes investors wary of their investors.

- Direct and indirect support from the government, such infrastructure development, facilitation, industrial parks and so forth would encourage entrepreneurship.

- While high taxes usually discourage entrepreneurship, tax holidays do the reverse.

- Positive legislation that reduces hurdles to starting and operating businesses encourages entrepreneurship.

Given that political reforms have far-reaching bearings on other areas including economic factors, monitoring and pro-acting to political instabilities ensures the business is aware of political pressures that may impact on its strategy and operations. This is particularly relevant in that political philosophies tend to transit political regimes in any country and understanding shifts in the dominant ideologies become essential to appreciating the impending direction of the business environment. As may be the case of South Africa, two important and recurring ideological issues that affect businesses, both formal 
and informal are the distribution of wealth between different groups in society and the role of the state versus the private sector in delivering goods and services. The perceived satisfaction with the delivery of vital services leads to the concept of social exclusion. The former describing a situation where designated people or areas suffer from a combination of linked problems such as unemployment, poor skills, low incomes, poor housing, high crime environments, bad health and family breakdown.

Despite the institutional supports provided by the government, Venter, Urban and Rwigema (2008) argue that the apparent limited entrepreneurial knowledge by natives in townships hinders their ability to spot and exploit business opportunities, which often translate into hostility against those who can.

\subsubsection{Hostility, conflict and entrepreneurship.} The association between hostility and entrepreneurship, and small businesses, in particular, is not well understood in scholarship. Perhaps this is due to a number of reasons, including the assumption of peace in most hypothetical models, the nonexistence of appropriate theories in economics about the causes and effects of conflict or hostility, the difficulty of collecting data in conflictaffected areas, and the pre-eminence of macrolevel approaches in political science.

The conduits through which entrepreneurs may benefit or suffer from violent conflict rest not only on the characteristics of the particular entrepreneur and firm but also on the type of violent conflict. In very intensive conflicts, a business may lose its employees (they may have fled or may be killed), and a business' main assets may be destroyed. If conflict affects a business in a onceoff, shock-like manner, then activities may be resumed following a cessation of violence, resulting in a temporary dip in profits. In contrast, a more persistent conflict may have a pernicious impact on firm-level investment and growth over the long term, and may result in a growing number of business failures.

3.3.2. Xenophobic attacks in SA. South Africa has made headline news a couple of times as far as xenophobia is concerned, with 2008 and 2015 still fresh in the minds of Somalis. Though African immigrants were the targets, Somali were affected most. Though beginning in the Johannesburg township of Alexandra, the violence quickly spread to other areas of the country. In the Western Cape province alone, the 2008, xenophobic riots against immigrants displaced closed to 20,000 foreign nationals and the Somali community was among those hit hard [IRIN, 2008].
3.4. Theories that underpin the study. A number of theories were elicited in an attempt to anchor this study.

3.4.1. The push-pull theory. The push-pull theory originating from migration studies have been widely used to explain the reasons why people migrate. In general terms, it posits that people turn to be either pushed or pulled to migrate. The push factors refer to negative or undesirable occurrences or factors that cause people to leave their home countries and travel to another country.

Unlike the former, the pull factors refer to those elements that entice people to a destination country. Relating this theory to entrepreneurship, one would suggest that push factors would cover those undesirable circumstances such as unemployment that force one to start up a business as a means of survival. Pull factors will be those aspects that entice a person to start a business (Tengeh et al., 2011; Dawson \& Henley, 2012). Examples of pull factors are higher wages, political stability, the high prospect of getting a job, better social amenities and so forth.

The migration literature with respect to entrepreneurship, therefore, suggests that migrants would establish businesses in South African townships both as a result of push and pull factors. Whether people are pushed or pulled into starting a business, the overarching rationale is the advancement of the well-being of the entrepreneur (Tengeh, 2013). The prevalence of instincts and common knowledge would therefore suggest that an entrepreneur would cease to operate or relocate a business once the pullpush factors no longer exists. Even more so, one would expect these entrepreneurs to quit if the pursuance of entrepreneurship threatens their very existance. However, we find that the push-pull theory is not well-grounded in this area and hence does not explain the propensity of entrepreneurs to endure life-threatening challenges as the case may be in South African townships.

\subsubsection{The Terror Management Theory (TMT).}

The terror management theory owes its origin to psychology. In as much as self-preservation is an inherent characteristic shared all organizms, the awareness of one's own mortality is peculiar to human beings. Such awareness presents a difficult problem for humans as they attempt to manage the terror that accompanies this type of knowledge (Pyszczynski, Greenberg \& Solomon, 1999). Supported by a number of studies, the theory demonstrates that self-esteem and worldviews provide protection against anxiety and death related cognition reminders (Pyszczynski et al., 1999; Greenberg \& Arndt, 2012). 
According to Greenberg and Arndt (2012), TMT starts with two simple observations. The first is that humans are animals with many systems designed to keep them alive, including a fight or flight response to impending threats to their continued existence. The second is that cognitive ability of humans has led to the awareness that death is inevitable and could come at any time due to a host of potential causes.

It is clear that most assessments of risks as pertaining to the push-pull factors of entrepreneurship is limited to the act and does not take into consideration other mitigating circumstances, such as the environment in which the act takes place including the safety of the entrepreneur (the one doing act). For entrepreneurship to flourish in volatile environments, in addition to having those entrepreneurs who are prepared to stake their monies there should be an "army" of fearless workers lured by different conditions who actually operate the ventures.

\section{Research method}

Anchored on the qualitative research design, focus groups provided the means for the collection and analysis of the data. Two groups of 6 and 7 informants were purposively selected to be part of the focus groups.

The target population was Somali immigrants in the South African township of Nomzamo in the Helderberg municipality of Cape Town. Nomzamo is just one of the townships in South Africa that has been repeatedly hit by xenophobic attacks. Somali immigrants were purposefully selected for this study for two reasons: Firstly, Somalis have probably been singled out for attacks more than any other African migrant community (IRIN, 2008). Secondly, Somalis suffered the most during these attacks on immigrants given that they operated most of the grocery shops in these townships. Thirdly, most Somali-owned grocery shops that were victims of xenophobia have since bounced back and flourished in the study site. In line with the aforementioned, studying grocery shops operated by Somalis was seen as the best route to follow, if one were to understand their resilience to adverse conditions as noted in these townships.
4.1. Formation of focus groups and analysis. The formation of the focus groups was informed by the fact that focus group interviews can successfully prompt information, perceptions, attitudes and ideas from a group in which each participant possesses experience with regards to the phenomenon under study (Kelly, 2003).

Using informants as the primary method of contact, other focus group members were recruited. Preliminary in-depth interviews were conducted with these informants who were later recruited to be part of the focus group. The process began with identifying key sources within the target population who understood the matter under investigation. A total of four informants were identified, and in this case comprised of two Somalis and two non-Somalis. These informants needed to have intensive knowledge of the population and issue under study.

A Preliminary assessment of the focus group members was conducted to ascertain their scope of knowledge with regards to the main questions under investigation. The composition the members of the focus group was diverse and made of landlords, suppliers to the Somalis shops, community leaders. In terms of gender, there were 12 men and a single female.

The focus group interviews were conducted according to a protocol previously prepared and tested in a pilot study. Care was taken in terms of ethical issues, place of application, experience of the moderator, sequence and duration of interview and recording of information. The group interviews were held in a silent and familiar environment to limit interferences. The interviews followed a series of open-ended questions.

The results of the focus group discussions were categorised around major themes which they provided. In quantitative studies, one are able to calculate in advance the extent of data needed to estimate the parameters accurately enough for the purpose of the analysis. Given that there are no similar methods for estimating the extent of qualitative data required, Stenius, Mäkelä, Miovsky \& Gabrhelik (2008) advise that we continue to add new cases until these addictions no longer disclose new information. In view of the aforementioned, our saturation point was reached when no new themes emerged.

\section{Findings and discussions}

\subsection{Background information.}

Table 1. Background data of the grocery shop operators

\begin{tabular}{|l|l|l|c|c|}
\hline \multicolumn{1}{|c|}{ Participants } & \multicolumn{1}{|c|}{ Experience/relevance } & \multicolumn{1}{c|}{ Relationship with business } & Focus Group A \\
\hline Grocery shop 1 & $\begin{array}{l}\text { First xenophobic attack, crime and } \\
\text { theft }\end{array}$ & $\begin{array}{l}\text { Co-ethnic, related to the owner and } \\
\text { received a salary. }\end{array}$ & $\mathrm{X}$ \\
\hline Grocery shop 2 & $\begin{array}{l}\text { Second xenophobic attack, crime and } \\
\text { theft }\end{array}$ & $\begin{array}{l}\text { Co-ethnic, and received salary } \\
\text { theft }\end{array}$ & $\begin{array}{l}\text { Co-ethnic, related to the owner and } \\
\text { shares profit. }\end{array}$ & $\mathrm{X}$ \\
\hline Grocery shop 3 & \multicolumn{2}{|l|}{ Second xenophobic attack, crime and } & \\
\hline
\end{tabular}


Table 1 (cont.). Background data of the grocery shop operators

\begin{tabular}{|l|l|l|c|c|}
\hline \multicolumn{1}{|c|}{ Participants } & \multicolumn{1}{|c|}{ Experience/relevance } & \multicolumn{1}{c|}{ Relationship with business } & Focus Group A & FocusGroup B \\
\hline Grocery shop 4 & Theft & Apprentice and salaried & X \\
\hline Grocery shop 5 & First xenophobic attack & & $\mathrm{X}$ & \\
\hline Grocery shop 6 & $\begin{array}{l}\text { Attempted violent robbery, second } \\
\text { xenophobic attack }\end{array}$ & & & $\mathrm{X}$ \\
\hline Grocery shop 7 & Victim of theft & Partner & $\mathrm{X}$ & \\
\hline Suppler 1 & Supplier of assorted products & No ownership or partnership relation & & $\mathrm{X}$ \\
\hline Supplier 2 & Supplier of assorted products & No ownership or partnership relation & $\mathrm{X}$ & \\
\hline Supplier 3 & Supplier of assorted products & Supplier and partner & & $\mathrm{X}$ \\
\hline Landlord 1 & Rents out property & No ownership or partnership relation & $\mathrm{X}$ & \\
\hline Landlord 2 & Rents out property & No ownership or partnership relation & & $\mathrm{X}$ \\
\hline Landlord 3 & Rents out property & No ownership or partnership relation & $\mathrm{X}$ & \\
\hline Total & & & 7 & 6 \\
\hline
\end{tabular}

Table 1, captures the basic background data of the participants. The six shop owners that participated were evenly assigned to the two focus groups. While two of the suppliers participated in the group B session 1 took part in the group A session, while two of the landlord that housed the shops of the participants took part in the group A session, 1 took part in the group B session. Overall, group A had 7 participants while B had 6 . Furthermore, Table 1 captured the experiences of the participants and categorised them in terms of the following themes:

- Resilience: It was noted by 10 of the participants that almost all of the current Somali grocery shops in the study area have been victims of crime and theft.

- Adversity: firstly, almost all of the Somali grocery shops that have been victims of the xenophobic attacks in the past have since returned to the township. Secondly, a majority of those operating the grocery shops are co-ethnics that work for a salary or shared profits.

The themes of resilience and adversity clearly indicate the propensity of Somali grocery shop owners' ability to bounce back.

5.2. What makes conducting a business in the township volatile or dangerous? The factors that make the township business environment volatile were grouped into 4 categories on the basis of the frequency that participants talked about them.

Table 2. Typical correlates of volatility

\begin{tabular}{|l|l|l|}
\hline Code & \multicolumn{1}{|c|}{ Theme } & \multicolumn{1}{c|}{ Results } \\
\hline A1.1 & Crime & $\begin{array}{l}\text { Crime: ten out of the 13 participants noted crime } \\
\text { as a constant threat to township business. }\end{array}$ \\
\hline A1.2 & Xenophobia & $\begin{array}{l}\text { Xenophobia: emerged as one of the factors that } \\
\text { make township operations precarious }\end{array}$ \\
\hline A1.3 & Competition & $\begin{array}{l}\text { Unhealthy Competition (further probed to mean } \\
\text { physically taking out your rivals in business.) }\end{array}$ \\
\hline A1.4 & Gangs & $\begin{array}{l}\text { Gangs or organized crime with unintended casu- } \\
\text { alties. }\end{array}$ \\
\hline
\end{tabular}

Among others, Table 2 hinges on the typical correlates of volatility in a township context, and in this case highlights crime, xenophobia competition and gangs. It is important to note that almost all (76\%) of the participants have been victims of crime at one stage. This verdict correlates with that of Naudé (2009) who notes that a volatile environment can be characterised by a number of factors not limited to crime, gangs and violence. In the context of townships in South Africa, Grastow and Amit (2012) reported the preponderance of the following forms of crime: opportunistic business robberies; Crimes orchestrated by South African traders against Somali competitors; crimes orchestrated by Somali traders against other foreign competitors; intimidation and attempted illegal evictions of Somali shops by South African competitors; robberies by police during police search operations; looting of shops by residents; and hijackings to name a few.

Noting that violent conflict has a devastating effect on the business environment, Naudé (2009) adds that though entrepreneurial activity is often steadfast during turbulent times, it has to adapt to modes that are sometimes not the best for economic development. In many ways, this assertion points to the need for intervention. Fierce competition among SA and Immigrant-owned business leads to crime; arson, business robbery and xenophobia in townships as a means of eradicating fierce competition, as this act of violence make entrepreneurship volatile (Charman et al., 2012; Grastow \& Amit 2012; Liedeman et al., 2013).

\subsection{What do township entrepreneurs worry or} fear most? In the quest to establish the degree of instability that these entrepreneurs face as they conduct their business, an inquest was made into what they feared most as far as safety was concerned. It was clear that the fear of the re-occurrence of the xenophobic attacks surpassed that of burglary, theft and death. As noted by Mohammed: 
"you know theft is everywhere and you may not lose everything in one go as the case may be during xenophobic attacks. With theft, we can predict and take steps to prevent them".

These results point in the direction of the terror management theory and perhaps highlights the degree to which the Somali grocery shop owners are able to manage their fears and this informs their resilience.

\subsection{What fuels Somali's persistence and prepon-} derance in townships? In an attempt to understand why immigrants keep on returning to South African townships despite perceiving it as volatile, the following came to the fore:

- It was noted that the challenges of starting a business, especially an informal one in the city or formal settlement were numerous and are not limited to the high overheads, competition from established shops. All of these make the competition tougher. Conversely, the township provides niche markets backed by high demand and low overheads. This assertion enforces the "pull factor" theory.

- The "push factor" was highlighted as one of the factors that push immigrants into townships. It was noted that most of those working in the Somali shops were ethnic workers working for a salary as well as learning the trade. Upon completion, they intend to open similar businesses in other townships. When asked why they take such a risk this is what Juba had to say: life itself is risky... we are used to similar or even worse circumstance". Drawing from Juba's statement, one can suggest that the cultural, physiological as well as physical challenges encountered by most Somali as a result of the instability at home, makes them motivated and resilient to adverse conditions.

"I am not scared of dying"said Juba, who flee from Somali a couple of years after the civil war broke out.

It is also worth noting that most of those who risk their lives are not the shop owners, but workers who work for a salary and/or profit sharing basis.

- In addition to being just workers, others indicated that they have no other skills and therefore cannot do anything else.

- Another reason for the preponderance of Somali immigrants in Somali township and grocery stores could attribute to their ability to network. However, another explanation may be what is referred to as herd behavior. By which newly arrived immigrants tend to conduct economic activities that they find their predecessors doing.
The recounted results correlate with the all too familiar "push-pull" thesis as noted in the current literature. For instance, Grastow and Amit (2012) note that a significant proportion of Somalis flee the civil war in their country to South Africa in search for better life.

\subsection{Risk aversion strategies of Somali entrepre-} neurs. The Somali system of business relies mostly on a quick turnover basis. They buy their goods in bulk from the suppliers or large supermarkets like Makro. These goods are later retailed to the township population with very minimal profits just to break-even but in the long run, the business survives. They also work very long hours as compared to the local entrepreneurs which give them an added advantage.

Furthermore, it was noted that most of the founders (here referred to as an entrepreneur) are not actively involved in running the shops. They simply recruit others to do so on their behalf. Under this circumstance, one may satisfactorily acknowledge that while, they are taking risks, which is a characteristic of entrepreneurs; the risk is limited to financial risk. Hence, they stand to lose just their investments in the event of undesirable events such as xenophobic attacks. This approach is quite different for other African immigrants in the same township. Given the ready supply of ethnic workers, their presence in these townships remains unperturbed in these years. In a bit to strengthen commitment, the managers are drawn in as partners or apprentices. In most cases, they are newly arrived immigrants from Somali who are not fully aware of the extent of the physical risks involved or simply do not have a choice. In other cases, they are those who have had failed businesses for themselves and are starting over.

Given that security is an issue in the townships, Somali entrepreneurs ensure that their business premises are well secured with bungler bars and "CCTV" surveillance cameras. They also work in pairs in order to better protect themselves from any business related violence.

\section{Conclusions and implications}

Many studies have echoed the need for a stable environment for economic development. Of particular importance has been the need for a conducive business environment for the startup and growth of business. Of course, this assertion is premised on the stability construct which underpins entrepreneurial prosperity. Assuming instability takes different forms and is not limited to wars, violence, unhealthy competition, gang wars, xenophobia and so forth, the literature presupposes that entrepreneurial activities decline in the face of such challenges. This notwithstanding, it has also been noted that some entrepreneurs or areas affected turn to bounce back sooner than others. 
South African townships have been a host of many immigrant entrepreneurs, and their numbers have risen over the past years. Interestingly, while the number of immigrants from different nations temporarily reduced after the xenophobic attacks, the numbers of Somali-owned shops have persistently been on the rise. Almost all that flee have returned. Against this backdrop, this paper investigated the preponderance of Somali grocery shops in South African township despite the perceived hostility of the business environment.

Prominent in the results was the fact that virtually all the current Somali grocery shops in the study area have been victims of crime and theft. Furthermore, practically all the Somali grocery shops that had been victims of the xenophobic attacks have since returned to the township. Enforcing one of the coping strategies, was the fact that a majority of those operating the grocery shops are co-ethnics that work on a salary or shared profits. The foregoing themes of resilience and adversity obviously indicate the propensity of Somali grocery shop owners' ability to bounce back. As to what township entrepreneurs worry or fear most, clearly, the fear of the re-occurrence of the xenophobic attacks surpassed that of burglary, theft and death. As to what fuels Somali's persistence and preponderance in townships, both push and pulled factors were reported. Reporting on risk aversion, it was noted that most of the founders (here referred to as an entrepreneur) are not actively involved in running the shops. They simply recruit others to do so on their behalf. Under this circumstance, one may satisfactorily acknowledge that while, they are taking risks, which is a characteristic of entrepreneurs; the risk is limited to financial risk. Hence, they stand to lose just their investments in the event of undesirable events such as xenophobic attacks. This approach is quite different for other African immigrants in the same township.

The findings of this paper have far-reaching implications in that understanding why certain groups of entrepreneurs or societies are more resilient to these hostile conditions than others may provide valuable lessons for others. This is especially true in the context of township businesses in South Africa where xenophobia and other adverse conditions have tested the resilience of African immigrant-owned businesses.

\section{Limitations}

The first drawback of this study is that it focuses on Somali immigrants who operate grocery shops in a selected township and therefore, making a generalisation is virtually impossible. The second limitation is embedded in our narrow definition of "unstable condition", which is limited to the violent attacks such as those encountered in South Africa in recent years.

\section{References}

1. Anderson, A.R. \& Starnawska, M. (2008). Problems of definition, description and meaning. International Journal of Entrepreneurship and Innovation, 9(4), pp. 221-230.

2. Bruck T., Naudé, W, \& Verwimp, P. (2013). Entrepreneurship and violent conflict in developing countries. WIDER Working Paper No. 2013/28.

3. Barringer, B.R. \& Ireland, R.D. (2010). Entrepreneurship: successfully launching new ventures. Upper Saddle River, New Jersey: Prentice Hall, $3^{\text {rd }}$ ed.

4. Charman, A., Petersen, L. \& Piper, L. (2012). From South African Survivalism to Foreign Entrepreneurship: The Transformation of the Spaza Sector in Delft, Cape Town. Transformation, 78, pp. 47-73.

5. Cramer, J.S., Joop Hartog, Nicole Jonker, and C. Mirjam van Praag (2002). Low-Risk Aversion Encourages the Choice for Entrepreneurship: an Empirical Test of a Truism. Journal of EconomicBehavior and Organization, 48, pp. 29-36.

6. De Vries, M.F.R.K. (1977). The entrepreneurial personality: A person at the crossroads. Management Studies, 14(1), pp. 3457.

7. De Vries, H., \& Shields, M. (2005). Entrepreneurial resilience: An analysis of the resilience factors in SME owner-managers. University of Central Arkansas working paper.

8. Duncan, N. (2010). Reaping the whirlwind: Xenophobic violence in South Africa. Invited presentation to the Third International Conference of Community Psychology, Community Agenda on Contemporary Social Problems, Universidad Iberoamericana, Puebla, Mexico.

9. Fairlie, W.R. (2009). Kauffman index of entrepreneurial activity 1996-2008, Kauffman Foundation.

10. Fuchs, K., Werner, A., \& Wallau, F. (2008). Entrepreneurship education in Germany and Sweden: What role do different school systems play? Journal of Small Business and Enterprise Development, 15(2), pp. 365-381.

11. Greenberg, J. \& Arndt, J. (2012). Terror Management Theory. In P.A.M. Van Lange, A.W. Kruglanski, \& E.T. Higgins (Eds.), Handbook of theories of social psychology, Vol. 1. Thousand Oaks, CA: SAGE. Handbook of theories of social Psychology, pp. 398-415.

12. Gastrow, V. \& Amit, R. (2012). Elusive justice: Somali traders' access to formal and informal justice mechanisms in the Western Cape. An ACMS Research Report. Available at: http://www.migration.org.za/uploads/docs/report38.pdf [21.09/16] 
13. Hedner, T., Abouzeedan, A, \& KLoften, M. (2011). Entrepreneurial resilience. Annals of Innovation \& Entrepreneurship, 2, p. 7986.

14. IRIN. (2008). Xenophobic attack spreading. Available at: www.irinnews.org. Accessed on 12/09/15.

15. Kelly, BT. (2003). Focus Group interviews. In FK Stage \& K. Mannin (Eds). Research in the college context: Approaches and methods. New York: Brunnes-Routledge, pp. 49-62.

16. Luthar, S., Cicchettit, D. \& Becker, B. (2000). The construct of resilience: A critical evaluation and guidelines for future work. Child Dev., 71(3), pp. 543-562.

17. Nieman, G. \& Nieuwenhuizen, C. (2009). Entrepreneurship: a South African perspective $2^{\text {nd }}$ ed. Pretoria: Van Schaik Publishers.

18. Nieman, G. and Pretorius, M. (2004). Managing growth. A guide for entrepreneurs. Cape Town: Juta and Co. Ltd.

19. Pyszczynski, T., Greenberg, J. \& Solomon, S. (1999). A Dual-Process Model of Defense Against Conscious and Unconscious Death-Related Thoughts An Extension of Terror Management Theory. Psychological Review, Vol. 106(4), pp. 835-845.

20. Rwigema, H \& Venter, R. (2004). Advanced Entrepreneurship. Oxford University Press: Southern Africa.

21. Sadeghi, M., Mohammadi, M., Nosrati, M., \& Malekian, K. (2013). The Role of Entrepreneurial Environments in University Students Entrepreneurial Intention. World Applied Programming, 3(8),361-366.

22. Stenius, K., Mäkelä, K., Miovsky, M., Gabrhelik, R. (2008). How to Write Publishable Qualitative Research. Publishing Addiction Science: A Guide for the Perplexed Second edition. Pp. 82-97 [http://www.parint.org/isajewebsite/isajebook2.htm]. Rockville, MD: International Society of Addiction Journal Editors.

23. Tengeh, R. (2013). Advancing the Case for the Support and Promotion of African Immigrant-Owned Businesses in South Africa. Mediterranean Journal of Social Sciences. 4(2), pp. 347-359.

24. The Economist (2007). Business resilience Ensuring continuity in a volatile environment. Available at: http://www.acegroup.com/se-en/assets/business-resiliance-62.pdf . [accessed 07/09/16].

25. Venter, R., Urban, B. \& Rwigema, H. (2008). Entrepreneurship: theory in practice. $2^{\text {nd }}$ ed. Cape Town: OUP.

26. Vromans, L., Schweitzer, R.D., Knoetze, K., \& Kagee, A. (2011). The Experience of Xenophobia in South Africa. American Journal of Orthopsychiatry, 81(1), pp. 90-93.

27. Wermer, E.E. \& Smith, R.S. (1992). Overcoming the odds: High-risk children from birth to adulthood. Cornell University Press, Ithaca. 